\title{
Identification and Frequency of Phytophthora Species Associated with Foliar Diseases in California Ornamental Nurseries
}

\author{
L. E. Yakabe, Department of Plant Pathology, University of California, Davis 95616; C. L. Blomquist and \\ S. L. Thomas, Plant and Pest Diagnostics Lab, California Department of Food and Agriculture, Sacramento 95831; \\ and J. D. MacDonald, Department of Plant Pathology, University of California, Davis 95616
}

\begin{abstract}
Yakabe, L. E., Blomquist, C. L., Thomas, S. L., and MacDonald, J. D. 2009. Identification and frequency of Phytophthora species associated with foliar diseases in California ornamental nurseries. Plant Dis. 93:883-890.

Numerous ornamental nurseries in 32 California counties were surveyed for leaf spots as part of the California Department of Food and Agriculture mandated surveys targeting Phytophthora ramorum. Tissue collected during the 2005 and 2006 surveys was initially screened by a Phytophthora-specific enzyme-linked immunosorbent assay. All positives samples were further tested using polymerase chain reaction to determine if $P$. ramorum was present. $P$. ramorum was detected in $1 \%$ of the total number of samples taken during the surveys. A total of 377 isolates were identified as species of Phytophthora other than P. ramorum, and their identity was determined by internal transcriber spacer (ITS) sequences. Subsets of the putative ITS-species were further verified using accepted morphological characters. Thirteen species of Phytophthora were found: P. cactorum, $P$. cambivora, $P$. citricola, $P$. citrophthora, $P$. cryptogea, $P$. foliorum, $P$. gonapodyides, $P$. hibernalis, $P$. nemorosa, $P$. 'Pgchlamydo', $P$. pseudosyringae, $P$. syringae, and $P$. tropicalis. $P$. syringae and $P$. citricola made up $55 \%$ of the total number of isolates. Species thought to be strictly forest pathogens, $P$. nemorosa and $P$. pseudosyringae, each made up less than $4 \%$ of the isolates. To test pathogenicity of acquired isolates, subsets of different species of Phytophthora were inoculated onto leaves of selected host plant genera. Of the 66 pathogenhost genera combinations tested, 44 resulted in lesion formation. Disease symptoms appeared as dark, water-soaked lesions with irregular margins and were similar among Phytophthora species.
\end{abstract}

Species of Phytophthora are present in virtually all ornamental nurseries and can cause significant disease problems. They are commonly introduced into nurseries through contaminated stock plants, contaminated media amendments, or contaminated irrigation water. Once introduced to a nursery block, inoculum is spread most commonly by splashing irrigation water and cultural practices such as potting, pruning, and moving plants $(10,11,17,29$, 31,45).

There are several species of Phytophthora reported to cause foliar diseases on ornamental plants. Phytophthora parasitica, $P$. citrophthora, and $P$. citricola are known to cause blights and leaf spots in Bougainvillea, Pieris, and Rhododendron, respectively $(1,7,18)$. Although surveys for Phytophthora have been conducted in Minnesota, North Carolina, and Tennessee, few have been done in the western United States $(15,41,46)$. Those species that cause leaf spots and twig blights, their relative frequency of occurrence, and the host

Corresponding author: J. D. MacDonald

E-mail: jdmacdonald@ucdavis.edu

Accepted for publication 15 May 2009.

doi:10.1094/PDIS-93-9-0883

(C) 2009 The American Phytopathological Society plants with which they are most commonly associated have remained largely unexplored.

The discovery of Phytophthora ramorum in western U.S. nurseries has brought diseases caused by Phytophthora under intense scrutiny. In 2000, $P$. ramorum was identified as the cause of a serious disease of oak and other tree species in California (38). This disease now occurs in the forest lands of 14 quarantined counties of coastal California and one county in southern Oregon. The recognition of $P$. ramorum as an important pathogen in nurseries has led to an awareness that this species has a wide host range that includes many ornamental plants $(39,47)$. Due to the concern that $P$. ramorum could move via the nursery trade, the United States Department of Agriculture-Animal and Plant Health Inspection Service (APHIS) published Interim Rule 7 CFR 301.92 in February 2002. Under rule 7, nurseries in states with $P$. ramorum infestations (California, Oregon, and Washington) may ship plants between states only if the shipping nursery has first been inspected and found free of $P$. ramorum. The inspections consist of a systematic sampling of all known hosts and associated plant taxa from each nursery growing ground. Both plants with suspicious symptoms and some asymptomatic plants are sampled and tested. In California, the inspections are conducted by trained county agricultural biologists, and testing is performed by the California Department of Food and Agriculture (CDFA) Plant and Pest Diagnostic Lab, which initially screens each submitted sample using a Phytophthora genus-level enzyme-linked immunosorbent assay (ELISA). Any samples that test positive by ELISA are subsequently tested using a polymerase chain reaction (PCR) specific for $P$. ramorum.

California is the nation's leading producer of ornamental plants with an annual farm-gate value of $\$ 3.5$ billion (5). Large amounts of plant material are exported regularly from California to locations across North America and around the world. As a result of the P. ramorum mandated inspections, hundreds of California ornamental nurseries have been extensively surveyed for leaf spots and twig blights over the past few years. In addition to finding $P$. ramorum in some nurseries, these surveys revealed numerous Phytophthora ELISA-positive, but $P$. ramorum PCR-negative foliar infections. This presented us with a unique opportunity to identify and partially characterize species of Phytophthora associated with foliar infections from approximately 40 genera of ornamental plants throughout major nursery production areas of California. This paper reports the results of this effort.

\section{MATERIALS AND METHODS}

Surveys. Ornamental nurseries from 32 counties in California were surveyed for leaf spots as part of the mandated nursery surveys conducted by the California Department of Food and Agriculture and the local county agricultural commissioners to detect $P$. ramorum. During the 2005 and 2006 sampling seasons (December 2004 through November 2005 and December 2005 through November 2006, respectively), nursery samples were obtained from wholesale and retail nurseries by trained county agricultural biologists. All samples were collected and processed in accordance with the APHIS survey and sampling protocol that requires visual inspection of all regulated host plants and known hosts associated with $P$. ramorum to detect leaf spots and twig blights (3). While sampling was biased toward these hosts, all plants showing obvious leaf lesions and twig blights were sampled. Individual plant samples containing anywhere 
from one to 80 leaves from a single species or variety block were bagged separately and sent to the CDFA laboratory for further processing. For the purposes of this study, a sample lot is defined as a group of samples from one growing location in one nursery during one sampling event. Each lot typically contained anywhere from one to 50 individual plant samples.

ELISA. From each sample, five or six pieces $(8-12 \times 5-6 \mathrm{~mm})$ of tissue were cut from the lesion margins on leaves or stems. The number of leaves or stems assayed per sample ranged from one to six depending on the symptoms and the number of leaves collected. Each of the pieces was divided into two, each half containing equal amounts of necrotic and healthy tissue. One set of halves was plated directly on CMA-PARP, a Phytophthoraselective medium (26). The other halves of these pieces were ground in $1 \mathrm{ml}$ of GEB2 buffer (Agdia, Elkhart, IN) using a Fast Prep machine (MP Biomedical, Solon, $\mathrm{OH})$, and $100 \mu \mathrm{l}$ of the grindate was tested in duplicate using a Phytophthora speciesspecific ELISA kit (Cat no. PSA 92600; Agdia). Tests were run according to manufacturer instructions. ELISAs were considered positive and warranted further testing by PCR if the OD 405 was at least twice the mean negative control.

Isolation. Tissue plated onto CMAPARP was stored at room temperature (20 to $25^{\circ} \mathrm{C}$ ) in the dark and monitored for hyphal growth for up to 14 days. Cultures identified as Phytophthora species other than $P$. ramorum by phenotypic characters (growth on CMA-PARP, colony morphol-

Table 1. GenBank reference sequences used in concert with accepted morphological characteristics for identifying Phytophthora species obtained during 2005 and 2006 field surveys of ornamental plants in California nurseries

\begin{tabular}{lc}
\hline Species $^{\mathbf{a}}$ & GenBank accession \\
\hline P. cactorum & AF266772 \\
P. cambivora & DQ338531 \\
& AF266763 \\
P. citricola & AY423291 \\
& DQ396418 \\
P. citrophthora & AF266788 \\
& AY769942 \\
& AF266785 \\
P. 'Pgchlamydo' & AY228572 \\
& AY961609 \\
P. hibernalis & AF541902 \\
& AY659416 \\
P. megasperma & AY787024 \\
& AF339442 \\
P. nemorosa & AY369370 \\
P. pseudosyringae & AF266375 \\
P. tropicalis & AY423298 \\
& DQ512954 \\
& AY332652 \\
& AY787032 \\
& AY787034 \\
AJ299734 & DQ357829 \\
\hline
\end{tabular}

a www.ncbi.nlm.nih.gov/GenBank/; 16,42. ogy, coenocytic mycelia, hyphal swellings) were subcultured onto V8 agar medium (V8A) $(16,32,42)$. Plugs of the V8A cultures were added to sterile water and hemp seed in vials and incubated at $4^{\circ} \mathrm{C}$ for long-term storage. Isolates of Phytophthora with similar morphological characteristics were grouped, and one of each group across all hosts per sample lot was selected for identification.

$P$. ramorum PCR identification. In addition to using morphological identification to verify presence of $P$. ramorum, DNA was extracted directly from leaf samples that tested positive by ELISA $(3,47)$. PCR was performed according to the USDA APHIS protocol (4). The nested PCR specific for $P$. ramorum is a variation of the nested PCR assay originally developed by Hayden et al. (23). The real-time (qPCR) test was implemented after March 2006 and is a variation of Hughes et al. (25).

Internal transcribed spacer (ITS) identification. One-week-old cultures, subcultured from the storage vials onto V8A, were used for DNA extraction. Aerial mycelia scraped from agar cultures and suspended in $1 \mathrm{ml}$ of sterile water were lysed using a sonicator (Sonic Dismembranator 100, Fisher Scientific, Hampton, $\mathrm{NH})$ for $20 \mathrm{~s}$ at 18 to 20 watts. A 900 base pair segment of the rDNA comprising a portion on the $18 \mathrm{~S}$ gene, ITS-1, 5.8S, ITS2 , and a portion of the $28 \mathrm{~S}$ gene was amplified by PCR using universal primers ITS1 and ITS4 (48). The following amplification parameters developed by White et al. (48) were used: $2 \mathrm{~min}$ at $95^{\circ} \mathrm{C}$ for initial denaturation, followed by 35 cycles of $30 \mathrm{~s}$ at $94^{\circ} \mathrm{C}, 30 \mathrm{~s}$ at $52^{\circ} \mathrm{C}$, and $1 \mathrm{~min}$ at $72^{\circ} \mathrm{C}$, with a final extension of $10 \mathrm{~min}$ at $72^{\circ} \mathrm{C}$. Amplicon concentration and length were verified by gel electrophoresis and purified using the QIAquick PCR Purification Kit (Qiagen, Valencia, CA) following manufacturer's instructions. Amplicons were sequenced using ITS4 by the University of California, Davis Division of Biological Sciences Automated DNA Sequencing Facility. Sequences were trimmed and edited in Vector NTI (Invitrogen, Carlsbad, CA) and then queried against those in GenBank (www.ncbi.nlm.nih.gov/Genbank/) for initial species identification using BLASTn. Final homology to selected reference sequences was determined using Clustal-X in Vector NTI. Reference sequences retrieved from GenBank and used for comparison with PCR amplicons are listed in Table 1. A Phytophthora species was assigned to an isolate if it matched reference sequences with 99.9 to $100 \%$ matching identity.

Morphological identification. Up to three isolates of each putative ITSidentified species were used to confirm species identification based on the comparison of isolate morphological characters to published descriptions $(16,42)$. Sporan- gia were produced by transferring 5-mm disks from colony margins grown on V8A into $15 \%$ nonsterile soil extract water and incubated at room temperature (20 to $25^{\circ} \mathrm{C}$ ) under lights. Sporangia were mounted in water, observed under a bright field illumination microscope (Olympus, Center Valley, PA) with a $40 \times$ objective, and measured with an eyepiece micrometer. The shape, caducity, and pedicel length of the sporangia were noted. Oospore induction was attempted by transferring isolates onto clarified V8A amended with $\beta$-sitosterol $(0.03 \mathrm{mg} / \mathrm{ml})$ and incubating them at room temperature under lights or in darkness for up to 30 days. If produced, oospores were measured by the same methods used for sporangia as mentioned above. Isolates were also transferred onto corn meal agar and clarified V8A to observe chlamydospores and hyphal swellings. Morphological characters and gross colony characters (fluffy, rosette, etc.) were compared against published descriptions $(16,42)$.

Pathogenicity tests. Putative hosts of the species of Phytophthora that were detected in the surveys belonged to 29 genera. The number of plants inoculated in our study was limited to species or cultivars of six genera due to the unavailability of some hosts and the limited amount of growth chamber space available for inoculations. As a result, host plants chosen for pathogenicity tests were selected from the genera most commonly associated with the species of Phytophthora that were determined by the survey procedures. Plants of the species or cultivars used in these inoculation experiments were chosen randomly from commonly grown container nursery stock. One gallon potted plants of six putative hosts: Rhododendron 'Unique' (hybrid of Rhododendron campylocarpum), Camellia japonica 'Korean Fire', Pieris japonica 'Variagata', Rhododendron sp. (azalea) 'Fielder's White' (hybrid of Rhododendron indica), Rhamnus alaternus 'John Edwards', and Photinia $\times$ fraseri, were inoculated with three isolates of each Phytophthora species to test pathogenicity. Pathogenicity of P. foliorum, P. gonapodyides, and $P$. 'Pgchlamydo' was not tested due to previously reported and concurrent projects investigating pathogenicity of these species (14; C. Blomquist, personal communication). Plants were maintained in growth chambers at $70 \%$ humidity with $24^{\circ} \mathrm{C}$ day and $15^{\circ} \mathrm{C}$ night temperatures and a 12-h photoperiod. Plants were inoculated when actively growing. Fully expanded new leaves were inoculated preferentially; however, a few older leaves were inoculated if needed to complete a full set of replications.

Inoculations were done by removing V8A culture plugs $(7 \mathrm{~mm}$ diameter) from the edge of a 5-day-old colony of each isolate, and placing two plugs in a waterfilled vial cap that was clipped onto the 


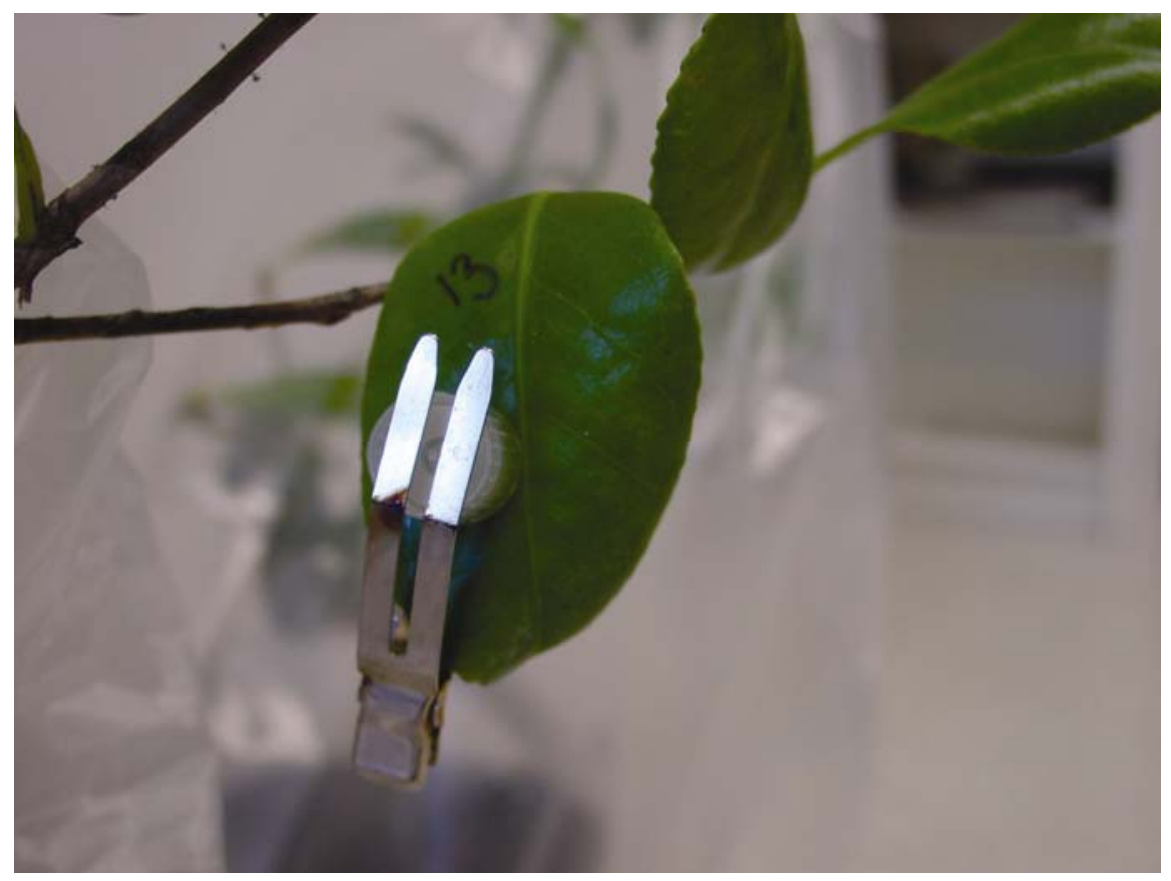

Fig. 1. Inoculation method for testing pathogenicity of acquired isolates of Phytophthora involved clipping plastic vial caps filled with colonized mycelial plugs of test species suspended in sterile water onto the adaxial side of a pin-pricked wounded leaf.

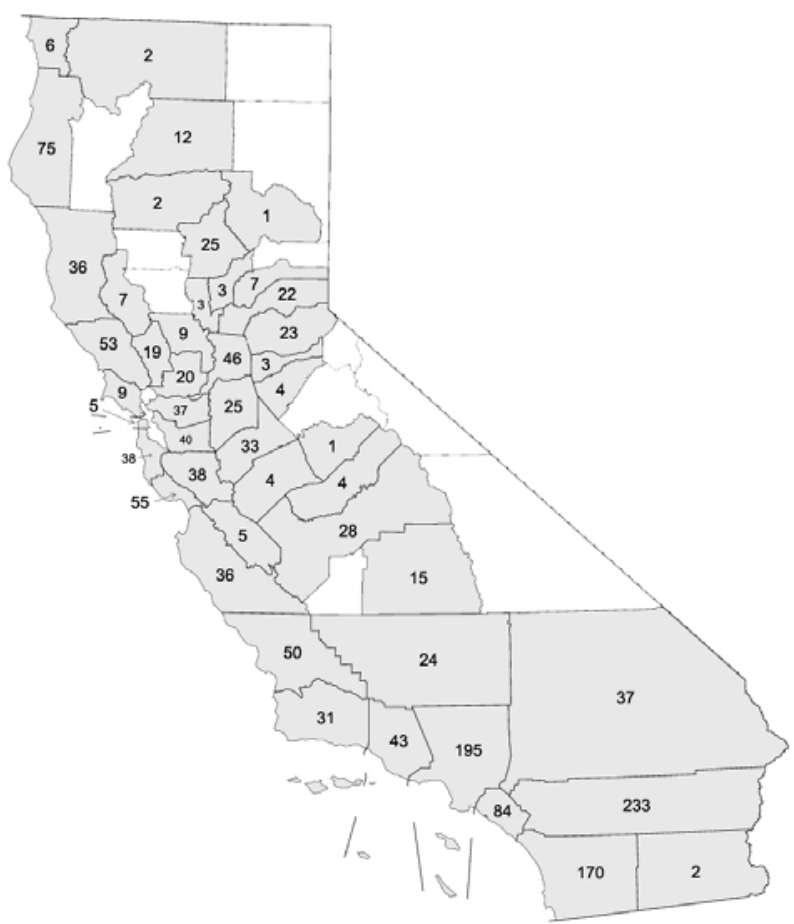

Fig. 2. Number and distribution of nurseries sampled by county in California during the 2005 and 2006 seasons for species of Phytophthora causing foliar disease symptoms on ornamental plants. adaxial surface of a wounded leaf for at least $48 \mathrm{~h}$ (Fig. 1). Sterile V8A agar plugs were used for the control treatments. Leaves were wounded by inserting a sterile push pin through each leaf just before inoculation. Only one isolate was inoculated onto a leaf. Up to 25 leaves per plant were inoculated with up to 11 Phytophthora species at one time. The caps and culture plugs were removed from the leaves immediately after lesion formation or in 10 days if lesions did not develop. Plants were incubated in high humidity growth chambers $(>90 \%)$ at 24 and $18^{\circ} \mathrm{C}$. When the caps and culture plugs were removed, both symptomatic and asymptomatic inoculated leaves were blotted on sterile paper towels and allowed to airdry for $6 \mathrm{~h}$ before being plated on CMAPARP to determine if the isolate was recoverable. Leaves were not surface-sterilized before plating. Plants were incubated for up to 10 days depending on the rate of lesion development.

Two trials of four inoculations on each host plant were conducted for each isolate. To determine the effect of temperature on lesion development, the frequency of development at 18 and $24^{\circ} \mathrm{C}$ for each species of Phytophthora were compared using chisquare analysis. Significant differences were determined using $P<0.05$.

\section{RESULTS}

During the 2005 and 2006 seasons, a total of 1,619 nurseries were surveyed in 32 counties in California. If a particular nursery location was sampled in both years, it counted as two nurseries. The numbers of nurseries sampled in each county are shown in Figure 2.

In each season, $41 \%$ (approximately 450) of the sample lots were positive for Phytophthora using ELISA. Of these, 9\% of the sample lots in 2005 and $8 \%$ in 2006 (a total of approximately 90 sample lots) tested positive for $P$. ramorum by PCR or culture isolation (Table 2). This incidence corresponded to 53 and 27 infected nurseries in 2005 and 2006, respectively (some nurseries had more than one positive sample lot). Eighteen of the 53 and 19 of the 27 nurseries had been found infested with $P$. ramorum the previous year, and were subject to quarantine action. The numbers of $P$. ramorum infested nurseries in 2005 and 2006 were lower than the 64 nurseries detected with this pathogen in 2004. Most

Table 2. Frequency of Phytophthora species in California nurseries obtained via field surveys during the 2005 and 2006 seasons

\begin{tabular}{lcccccc}
\hline Season & $\begin{array}{c}\text { Number } \\
\text { of lots }^{\mathbf{a}}\end{array}$ & $\begin{array}{c}\text { Percent lots Phytophthora } \\
\text { ELISA positiveb }^{\mathbf{b}}\end{array}$ & $\begin{array}{c}\text { Percent lots } \\
\text { P. } \text { ramorum } \text { positive }^{\mathbf{c}}\end{array}$ & $\begin{array}{c}\text { Number } \\
\text { of samples }\end{array}$ & $\begin{array}{c}\text { Percent samples } \\
\text { Phytophthora } \text { ELISA positive }^{\mathbf{b}}\end{array}$ & $\begin{array}{c}\text { Percent samples } \\
\text { P. ramorum } \text { positive }^{\mathbf{c}}\end{array}$ \\
\hline 2005 & 1,167 & $41 \%$ & $9 \%$ & 25,139 & $6 \%$ & $1 \%$ \\
2006 & 1,190 & $41 \%$ & $8 \%$ & 25,982 & $6 \%$ & $1 \%$ \\
\hline
\end{tabular}

${ }^{a}$ Lots are groups of samples taken from one growing location during one sampling event.

${ }^{\mathrm{b}}$ Phytophthora was determined to be present if the enzyme-linked immunosorbent assay (ELISA) sample test had twice the optical density of the mean negative control. This criterion overestimates true positives because the test cross-reacts with some Pythium species and host materials. Positive ELISA samples did not always yield Phytophthora cultures.

${ }^{c} P$. ramorum presence was verified by culture morphology or positive nested polymerase chain reaction (PCR), restriction fragment length polymorphism (RFLP), or qPCR. 
of the infested nurseries in 2005 and 2006 were in quarantine counties located in the central coast region.

A total of 232 Phytophthora isolates from 2005, and 145 from 2006 that were not $P$. ramorum, were identified to the species level. Microscopic examination of selected isolates of each putative ITS species showed that they matched against previously published species descriptions of the morphology of sporangia, morphology, chlamydospores, oospores, and hyphal swellings.

Thirteen species of Phytophthora were identified among the tested isolates (Table $3)$. The frequency of isolation of each species varied within $10 \%$ between both sampling seasons: $P$. citricola and $P$. syringae were the species most frequently recovered, comprising 25 and $30 \%$ of the identified isolates, respectively. In descending order of isolation frequency, with each comprising less than $10 \%$ of the total isolates, were: $P$. cactorum, $P$. 'Pgchlamydo', P. citrophthora, $P$. foliorum, $P$. hibernalis, $P$. nemorosa, $P$. pseudosyringae, $P$. gonapodyides, and $P$. tropicalis. $P$. cambivora ( $0.5 \%$ of the isolates) was isolated in 2005 only. P. cryptogea, a species commonly encountered from infected roots and contaminated irrigation water, was isolated in 2006 only and comprised $0.3 \%$ of the total isolates (Table 3). Phytophthora species were isolated most frequently from broadleaved, evergreen hosts.

Pathogenicity was confirmed on three or more host plant species for most of the Phytophthora species tested under the conditions of these trials (Table 4). The exceptions were $P$. hibernalis and $P$. nemorosa, where pathogenicity was verified only on Rhododendron and Pieris, respectively. Altogether, 66 pathogen-host genera combinations were tested. Twentyeight pathogen-host combinations were observed in the nursery surveys. Pathogenicity tests confirmed 19 of those observed in the nursery surveys. Twenty-five potential pathogen-host combinations were identified from inoculations of hostpathogen combinations not found in the nursery survey. Phytophthora species were never isolated from asymptomatic leaves. Lesions were similar in appearance between Phytophthora species. All leaf lesions appeared as dark, water-soaked spots with somewhat irregular margins. Lesions developed as frequently on older leaves as on fully mature younger leaves. Lesion development by some Phytophthora species was affected by incubation temperature, developing more reliably at the temperature closest to the Phytophthora species' published growth optimum (16). Lesions caused by $P$. hibernalis, $P$. nemorosa, $P$. pseudosyringae, and $P$. syringae, species with optimal growth temperatures between 15 and $20^{\circ} \mathrm{C}$, formed more frequently when pathogenicity tests were conducted at $18^{\circ} \mathrm{C}$. Lesions caused by $P$. citricola and $P$. citrophthora, species with optimal growth temperatures between 24 and $28^{\circ} \mathrm{C}$, formed more frequently when pathogenicity tests were conducted at $24^{\circ} \mathrm{C}$. Lesions caused by other species with optimal growth temperatures between 24 and $28^{\circ} \mathrm{C}, P$. cactorum, $P$. cambivora, $P$. cryptogea, $P$. gonapodyides, and $P$. tropicalis, developed as frequently at 18 and $24^{\circ} \mathrm{C}$.

\section{DISCUSSION}

Leaf spots and twig blights occur commonly on nursery plants and are not always associated with Phytophthora species or any other biotic plant disease. In these surveys, however, $41 \%$ of the sample lots processed tested positive for Phytophthora by ELISA. The low threshold for detection may have overestimated the number of samples infected with Phytophthora spe- cies. On the other hand, the large proportion of positives may emphasize how overhead irrigation, commonly used in many nurseries, favors Phytophthora survival and spread even in the dry climates of California.

Eleven of the 13 Phytophthora species recovered in this study occur on potting media and ornamental plants in the United States: $P$. cactorum, $P$. cambivora, $P$. citricola, $P$. cryptogea, $P$. citrophthora, $P$. foliorum, $P$. gonapodyides, $P$. hibernalis, $P$. 'Pgchlamydo', $P$. syringae, and $P$. tropicalis. In California, $P$. foliorum causes disease on evergreen azaleas, and $P$. citrophthora, $P$. citricola, and $P$. cryptogea are present in nursery effluents $(14,29)$. $P$. cactorum, $P$. citricola, $P$. citrophthora, $P$. foliorum, and $P$. tropicalis cause disease in woody ornamentals in Tennessee $(14,15)$. P. citrophthora, P. citricola, $P$. cryptogea,

Table 3. Frequency of Phytophthora species other than P. ramorum isolated from California ornamental nursery stock during the 2005 and 2006 seasons $^{\mathrm{a}}$

\begin{tabular}{|c|c|c|}
\hline Phytophthora species $^{b}$ & Host genus & No. of isolates \\
\hline \multirow{8}{*}{ P. cactorum } & Archtostaphylous & 1 \\
\hline & Eucalyptus & 1 \\
\hline & Photinia & 11 \\
\hline & Pyracantha & 5 \\
\hline & Rhamnus & 11 \\
\hline & Sequoia & 1 \\
\hline & Toyon & 2 \\
\hline & Viburnum & 2 \\
\hline \multirow[t]{2}{*}{ P. cambivora } & Areca & 1 \\
\hline & Quercus & 1 \\
\hline \multirow[t]{18}{*}{ P. citricola } & Arbutus & 10 \\
\hline & Archtostaphylous & 4 \\
\hline & Ardisia & 1 \\
\hline & Rhododendron (azalea) & 22 \\
\hline & Camellia & 16 \\
\hline & Cupaniopsis & 1 \\
\hline & Laurus & 7 \\
\hline & Magnolia & 1 \\
\hline & Myrtus & 1 \\
\hline & Photinia & 3 \\
\hline & Pieris & 4 \\
\hline & Pyracantha & 1 \\
\hline & Ribes & 1 \\
\hline & Rhamnus & 7 \\
\hline & Rhododendron & 6 \\
\hline & Sequoia & 1 \\
\hline & Syringa & 5 \\
\hline & Tristania & 4 \\
\hline \multirow[t]{7}{*}{ P. citrophthora } & Arbutus & 2 \\
\hline & Archtostaphylous & 4 \\
\hline & Rhododendron (azalea) & 9 \\
\hline & Camellia & 3 \\
\hline & Ficus & 1 \\
\hline & Laurus & 2 \\
\hline & Pieris & 6 \\
\hline P. cryptogea & Arbutus & 1 \\
\hline P. foliorum & Azalea & 27 \\
\hline \multirow[t]{3}{*}{ P. gonapodyides } & Arbutus & 3 \\
\hline & Laurus & 1 \\
\hline & Sequoia & 1 \\
\hline \multirow[t]{4}{*}{ P. hibernalis } & Rhododendron (azalea) & 1 \\
\hline & Camellia & 1 \\
\hline & Photinia & 3 \\
\hline & Pieris & 6 \\
\hline
\end{tabular}

(continued on next page)

\footnotetext{
a Isolates were identified by internal transcribed spacer (ITS) sequences with 99.9 to $100 \%$ correspondence to reference sequences of known Phytophthora species in GenBank, and morphological verification was conducted on a subset of isolates.

b www.ncbi.nlm.nih.gov/GenBank/; 16,42.
} 
and $P$. tropicalis were found in recycled nursery irrigation water in Virginia $(10,11,24)$. $P$. cactorum is common in Minnesota nurseries where $P$. 'Pgchlamydo', $P$. cambivora, $P$. citricola, and $P$. citrophthora are less common (41). In the southeastern United States, $P$. cactorum, $P$. citrophthora, $P$. citricola, and $P$. cryptogea were isolated in naturally infested potting media, and P. citricola, P. cambivora, and $P$. cactorum were isolated from Rhododendron and Pieris $(17,46)$.

Many of these same Phytophthora species are found in Europe, Asia, and Australia. With the exception of $P$. tropicalis, 10 of the common Phytophthora species detected in this study were found in nursery effluent water in Germany (43). P. citricola was detected on Rhododendron, Fagus sylvatica, and Abies alba in Polish nurseries and in potting mix in Australia
$(13,34,36,37)$. P. cryptogea infected several nursery plant species in Poland and Australia (22,35). P. cactorum was found on plants and in water in Finnish forest nurseries and in Korea on diseased Avalia elata $(28,40)$. P. hibernalis infected Rhododendron in Spain (2). Several of these same Phytophthora species are also found in natural landscapes throughout the world $(6,17,21)$. In addition to foliar infections, these Phytophthora species cause root diseases (16). While there are many separate reports of these species in nurseries worldwide, this study showed that many Phytophthora species were widespread in the nurseries surveyed across California.

$P$. nemorosa and P. pseudosyringae are recently described species that were initially detected as forest pathogens $(20,27)$. They have similar host ranges and occur in generally the same geographic region as $P$.

Table 3. (Continued from previous page)

\begin{tabular}{|c|c|c|}
\hline Phytophthora species $^{\mathrm{b}}$ & Host genus & No. of isolates \\
\hline \multirow[t]{2}{*}{ P. hibernalis (continued) } & Rhododendron & 2 \\
\hline & Xylosma & 2 \\
\hline \multirow[t]{5}{*}{ P. nemorosa } & Camellia & 5 \\
\hline & Laurus & 1 \\
\hline & Osmanthus & 2 \\
\hline & Pieris & 5 \\
\hline & Rhododendron & 1 \\
\hline \multirow[t]{12}{*}{ P. 'Pgchlamydo' } & Arbutus & 11 \\
\hline & Rhododendron (azalea) & 4 \\
\hline & Bихиs & 1 \\
\hline & Camellia & 4 \\
\hline & Laurus & 3 \\
\hline & Magnolia & 1 \\
\hline & Pyrus & 2 \\
\hline & Rhamnus & 1 \\
\hline & Rhododendron & 1 \\
\hline & Sequoia & 4 \\
\hline & Tristania & 1 \\
\hline & Viburnum & 1 \\
\hline \multirow[t]{4}{*}{ P. pseudosyringae } & Rhododendron (azalea) & 2 \\
\hline & Camellia & 3 \\
\hline & Laurus & 1 \\
\hline & Pieris & 1 \\
\hline \multirow[t]{4}{*}{ P. pseudosyringae } & Rhododendron (azalea) & 2 \\
\hline & Camellia & 3 \\
\hline & Laurus & 1 \\
\hline & Pieris & 1 \\
\hline \multirow{21}{*}{ P. syringae } & Arbutus & 13 \\
\hline & Archtostaphylous & 7 \\
\hline & Ardisia & 1 \\
\hline & Rhododendron (azalea) & 4 \\
\hline & Brachychiton & 1 \\
\hline & Camellia & 6 \\
\hline & Ceanothus & 1 \\
\hline & Escalonia & 1 \\
\hline & Ficus & 1 \\
\hline & Laurus & 3 \\
\hline & Lonicera & 1 \\
\hline & Magnolia & 6 \\
\hline & Osmanthus & 1 \\
\hline & Photinia & 14 \\
\hline & Pieris & 7 \\
\hline & Pyracantha & 11 \\
\hline & Rhamnus & 2 \\
\hline & Rhododendron & 21 \\
\hline & Syringa & 1 \\
\hline & Tristania & 5 \\
\hline & Viburnum & 6 \\
\hline P. tropicalis & Camellia & 3 \\
\hline Total & & 377 \\
\hline
\end{tabular}

ramorum in California forests, but are genetically related to $P$. ilicis $(30,49)$. $P$. pseudosyringae causes a root and collar rot in deciduous oak and alder trees in Europe (27). In California and Oregon forests, it is mainly associated with leaf spots and twig blights on a few hosts as well as cankers on coast live oak (Quercus agrifolia) $(19,40)$. Also in California and Oregon forests, $P$. nemorosa causes leaf spots and twig blights and is occasionally associated with trunk cankers on tanoak (Lithocarpus densiflorus) (18). This survey is the first confirmed detection of these two pathogens in California nurseries. P. nemorosa recently has been reported causing leaf spots on Camellia in an Oregon nursery (N. Grunwald, personal communication), and $P$. pseudosyringae has been reported causing disease on chestnut nursery stock in Spain (44). This report expands the host ranges of these two species.

$P$. 'Pgchlamydo' (GenBank accession numbers AF541902 and AY787024) is an undescribed but distinct variant of $P$. $g o$ napodyides $(9,19)$. Frequently isolated from streams and soil, $P$. 'Pgchlamydo' has also been found causing leaf spots in Minnesota nurseries on Rhododendron and Taxus species (41). This study indicates that $P$. 'Pgchlamydo' is also present in California nurseries and is associated with leaf spots on at least eight genera of plants including Rhododendron.

Braiser (8), followed by Cooke et al. (12), put forth the hypothesis that two evolutionary lines exist in the genus Phytophthora. One line evolved papillate, caducous sporangia that are more adapted to an aerial mode of dispersal, whereas a second line evolved toward nonpapillate, noncaducous sporangia that are better adapted to a soilborne habit. While not finding evidence to support or reject this hypothesis, this survey indicates that noncaducous sporangia do not preclude Phytophthora species from causing foliar infections. $P$. syringae and $P$. citricola, the most prevalent species found in these surveys of foliar tissue, have noncaducous sporangia. Noncaducous sporangia can be dispersed through contaminated water that is used for overhead irrigation or through contaminated potting media that can splash onto foliage through nursery cultural practices or rain. Zoospores alone, after release from caducous or noncaducous sporangia, can also be dispersed through water splash. These observations regarding noncaducous sporangia have been noted in other pathosystems. For example, $P$. nicotianae, a species with noncaducous sporangia, causes foliar and fruit infections on processing tomatoes. Infection by $P$. nicotianae is facilitated by flooded irrigation water that brings soil containing inoculum into contact with ripening fruit (33). In a container nursery system, clean potting media and clean irrigation water are as important as clean stock in preventing disease. 
Table 4. Pathogenicity of selected isolates of Phytophthora on selected host species ${ }^{\mathrm{a}}$

\begin{tabular}{|c|c|c|c|c|c|c|c|}
\hline \multirow[b]{3}{*}{ Phytophthora species } & \multirow[b]{3}{*}{ Host } & \multicolumn{6}{|c|}{ Number of pathogenic interactions out of eight leaf inoculations } \\
\hline & & \multicolumn{3}{|c|}{ Isolate $\left(\mathbf{1 8}^{\circ} \mathbf{C}\right)$} & \multicolumn{3}{|c|}{ Isolate $\left(24^{\circ} \mathrm{C}\right)$} \\
\hline & & 1 & 2 & 3 & 1 & 2 & 3 \\
\hline \multirow[t]{6}{*}{ P. cactorum } & Rhododendron (azalea) & 0 & 8 & 0 & 6 & 0 & 3 \\
\hline & Camelia & 8 & 8 & 8 & 8 & 8 & 8 \\
\hline & Pieris & 8 & 8 & 8 & 8 & 8 & 8 \\
\hline & Photinia & $8^{\mathrm{b}}$ & 8 & 8 & $8^{\mathrm{b}}$ & 8 & 8 \\
\hline & Rhamnus & 0 & $0^{\mathrm{b}}$ & 0 & 0 & $0^{\mathrm{b}}$ & 0 \\
\hline & Rhododendron & 8 & 8 & 8 & 8 & 8 & 8 \\
\hline \multirow[t]{6}{*}{ P. cambivora } & Rhododendron (azalea) & 0 & 0 & $\ldots$ & 0 & 0 & $\ldots$ \\
\hline & Camelia & 7 & 7 & $\ldots$ & 7 & 6 & $\ldots$ \\
\hline & Pieris & 6 & 8 & $\ldots$ & 8 & 8 & $\ldots$ \\
\hline & Photinia & 8 & 8 & $\ldots$ & 6 & 6 & $\ldots$ \\
\hline & Rhamnus & 0 & 0 & $\ldots$ & 0 & 0 & $\ldots$ \\
\hline & Rhododendron & 8 & 8 & $\begin{array}{l}\cdots \\
\ldots\end{array}$ & 8 & 8 & $\begin{array}{l}\cdots \\
\cdots\end{array}$ \\
\hline \multirow[t]{6}{*}{ P. citricola } & Rhododendron (azalea) & 0 & 8 & $8^{\mathrm{b}}$ & 8 & 8 & $8^{\mathrm{b}}$ \\
\hline & Camelia & 7 & 7 & 7 & 6 & 6 & 8 \\
\hline & Pieris & 8 & $8^{\mathrm{b}}$ & 8 & 8 & $8^{\mathrm{b}}$ & 8 \\
\hline & Photinia & 0 & 0 & 0 & 8 & 8 & 8 \\
\hline & Rhamnus & 8 & 8 & 8 & 8 & 8 & 8 \\
\hline & Rhododendron & $8^{\mathrm{b}}$ & 8 & 8 & $8^{\mathrm{b}}$ & 8 & 8 \\
\hline \multirow[t]{6}{*}{ P. citrophthora } & Rhododendron (azalea) & $4^{\mathrm{b}}$ & 4 & 8 & $8^{\mathrm{b}}$ & 8 & 8 \\
\hline & Camelia & 6 & 6 & 7 & 8 & 7 & 7 \\
\hline & Pieris & 8 & 8 & $8^{\mathrm{b}}$ & 8 & 8 & $8^{\mathrm{b}}$ \\
\hline & Photinia & 8 & 8 & 8 & 8 & 8 & 8 \\
\hline & Rhamnus & 8 & 8 & 8 & 8 & 8 & 8 \\
\hline & Rhododendron & 8 & 8 & 8 & 8 & 8 & 8 \\
\hline \multirow{6}{*}{ P. cryptogea } & Rhododendron (azalea) & 8 & $\ldots$ & $\ldots$ & 8 & $\ldots$ & $\ldots$ \\
\hline & Camelia & 8 & $\ldots$ & $\ldots$ & 8 & $\ldots$ & $\ldots$ \\
\hline & Pieris & 8 & $\ldots$ & $\ldots$ & 8 & $\ldots$ & $\ldots$ \\
\hline & Photinia & 0 & $\ldots$ & $\ldots$ & 0 & $\ldots$ & $\ldots$ \\
\hline & Rhamnus & 0 & $\cdots$ & $\ldots$ & 0 & $\ldots$ & $\ldots$ \\
\hline & Rhododendron & 8 & $\ldots$ & $\ldots$ & 8 & $\ldots$ & $\ldots$ \\
\hline \multirow[t]{6}{*}{ P. gonapodyides } & Rhododendron (azalea) & 0 & 0 & 0 & 0 & $\ddot{0}$ & 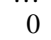 \\
\hline & Camelia & 0 & 1 & 0 & 0 & 1 & 2 \\
\hline & Pieris & 2 & 5 & 2 & 8 & 8 & 7 \\
\hline & Photinia & 7 & 5 & 0 & 4 & 1 & 5 \\
\hline & Rhamnus & 8 & 8 & 8 & 8 & 8 & 8 \\
\hline & Rhododendron & 8 & 8 & 8 & 8 & 7 & 8 \\
\hline P. hibernalis & Rhododendron (azalea) & $0^{\mathrm{b}}$ & 0 & 0 & $0^{\mathrm{b}}$ & 0 & 0 \\
\hline & Camelia & 0 & 0 & 0 & 0 & 0 & 0 \\
\hline & Pieris & 0 & 0 & $0^{\mathrm{b}}$ & 0 & 0 & $0^{\mathrm{b}}$ \\
\hline & Photinia & 0 & 0 & 0 & 0 & 0 & 0 \\
\hline & Rhamnus & 0 & 0 & 0 & 0 & 0 & 0 \\
\hline & Rhododendron & 8 & $5^{\mathrm{b}}$ & 8 & 0 & $0^{\mathrm{b}}$ & 0 \\
\hline P. nemorosa & Rhododendron (azalea) & 0 & 0 & 0 & 0 & 0 & 0 \\
\hline & Camelia & 0 & $0^{\mathrm{b}}$ & $0^{\mathrm{b}}$ & 0 & $0^{\mathrm{b}}$ & $0^{\mathrm{b}}$ \\
\hline & Pieris & $8^{\mathrm{b}}$ & 7 & 8 & $0^{\mathrm{b}}$ & 0 & 1 \\
\hline & Photinia & 0 & 0 & 0 & 0 & 0 & 0 \\
\hline & Rhamnus & 0 & 0 & 0 & 0 & 0 & 0 \\
\hline & Rhododendron & 0 & 0 & 0 & 0 & 0 & 0 \\
\hline P. pseudosyringae & Rhododendron (azalea) & 0 & 0 & $0^{\mathrm{b}}$ & 0 & 0 & $0^{\mathrm{b}}$ \\
\hline & Camelia & $1^{\mathrm{b}}$ & 1 & 0 & $2^{\mathrm{b}}$ & 0 & 2 \\
\hline & Pieris & 8 & 0 & 4 & 2 & 0 & 3 \\
\hline & Photinia & 8 & 0 & 0 & 4 & 0 & 0 \\
\hline & Rhamnus & 0 & 0 & 0 & 0 & 0 & 0 \\
\hline & Rhododendron & 8 & 0 & 8 & 0 & 0 & 0 \\
\hline P. syringae & Rhododendron (azalea) & 5 & 1 & 2 & 0 & 0 & 0 \\
\hline & Camelia & 8 & 6 & $6^{\mathrm{b}}$ & 3 & 5 & $5^{\mathrm{b}}$ \\
\hline & Pieris & 8 & $2^{b}$ & 8 & 1 & $0^{\mathrm{b}}$ & 1 \\
\hline & Photinia & 4 & 2 & 8 & 0 & 0 & 0 \\
\hline & Rhamnus & 0 & 0 & 0 & 0 & 0 & 0 \\
\hline & Rhododendron & $7^{\mathrm{b}}$ & 8 & 8 & $0^{\mathrm{b}}$ & 0 & 0 \\
\hline P. tropicalis & Rhododendron (azalea) & 0 & 0 & $\ldots$ & 0 & 0 & $\ldots$ \\
\hline & Camelia & $7^{\mathrm{b}}$ & $7^{\mathrm{b}}$ & $\ldots$ & $8^{\mathrm{b}}$ & $7^{\mathrm{b}}$ & $\ldots$ \\
\hline & Pieris & 3 & 2 & $\ldots$ & 6 & 7 & $\ldots$ \\
\hline & Photinia & 0 & 0 & $\ldots$ & 0 & 0 & $\ldots$ \\
\hline & Rhamnus & 0 & 0 & $\ldots$ & 0 & 0 & $\ldots$ \\
\hline & Rhododendron & 6 & 7 & $\ldots$ & 8 & 8 & $\ldots$ \\
\hline
\end{tabular}

a An interaction was determined to be pathogenic if the inoculated leaf developed a lesion and the isolate was recovered from the lesion. An interaction was considered not to be pathogenic if the isolate was not recovered from the lesion. Asymptomatic infections and recovery of an isolate from asymptomatic inoculation sites did not occur under these experimental conditions.

${ }^{\mathrm{b}}$ Isolates obtained initially from the host genera tested. 
The Phytophthora species recovered in this study caused leaf lesions on a wide range of hosts. Most of these hosts were evergreen species. Evergreen species retain foliage in the winter when most of the rainfall occurs in California. The combination of susceptible tissue and favorable climate likely makes evergreen plant species more prone to foliar Phytophthora diseases in California. Pathogenicity tests were designed to favor disease development on foliage. Mycelia in water on a wounded, newly expanded leaf favors infection by the pathogen and does not predict that disease will occur in all environmental conditions. Additionally, more variation in disease incidence may occur if leaves were inoculated with sporangia or zoospores or if leaves were left unwounded. These pathogenicity tests were not intended to demonstrate disease severity or incidence in a nursery situation, but were designed to test the potential host range of each Phytophthora species tested and to look for similarities in leaf lesion appearance and development. Additionally, pathogenicity was tested on one cultivar of each host species. Pathogenicity was not confirmed in leaf inoculation tests for all isolates obtained from symptomatic plants of the six selected host. This response was notable with $P$. hibernalis and $P$. nemorosa. The authors suspect that because these species are rarely pathogenic on these hosts, the cultivars chosen for testing were not as susceptible to infection as the original host material or the inoculation conditions were not optimal for infection and lesion development. No asymptomatic infections were detected. This close association of colonization and lesion formation speaks to the aggressive nature of the pathogenicity test methods.

In pathogenicity tests, lesion development on several species was affected by temperature. Pathogenicity of the cool weather (optimal growth temperatures 15 to $20^{\circ} \mathrm{C}$ ) species produced lesions consistently at $18^{\circ} \mathrm{C}$ as compared to $24^{\circ} \mathrm{C}$. Pathogenicity of the warm weather species (optimal growth temperatures 24 to $28^{\circ} \mathrm{C}$ ) were not dramatically influenced by temperature, except for $P$. citricola and $P$. citrophthora, which produced lesions more consistently at $24^{\circ} \mathrm{C}$ than at $18^{\circ} \mathrm{C}$. Lesion development and appearance, regardless of temperature, was similar among species of Phytophthora, so it is unlikely that Phytophthora species can be identified by lesion characteristics alone in environmental samples.

This study of Phytophthora species associated with foliar infections in nursery plants covered a broad geographic region. The statewide survey for Phytophthora ramorum presented an opportunity to establish a baseline for Phytophthora species diversity, their relative frequency of occurrence, and a list of commonly associated host plants in nursery environments. Re- sults of this study do not highlight one Phytophthora species on particular hosts, but rather emphasize the significance of many Phytophthora species on a wide range of hosts in many nursery locations. Historically, Phytophthora species are studied as root and crown rot associated organisms; however, this study has shown many Phytophthora species are equally capable of infecting foliar plant parts. Little is known about the overall impact of Phytophthora diseases infecting the foliage of ornamental plants or how modern nursery management practices affect the epidemiology of these diseases. Standard nursery practices use prophylactic treatments with fungicides to suppress the occurrence of Phytophthora and other foliar fungal diseases. Phytophthora species are likely to be more prevalent than is indicated in the survey. In the survey, inspectors sampled leaves with disease symptoms. This means that the survey only detected Phytophthora species not affected by fungicides or that escaped fungicide applications. Additionally, species causing infections that are asymptomatic would likely be overlooked or underestimated since sampling was biased toward symptomatic leaves. Phytophthora diseases would likely become more prevalent without the use of fungicides or without proper fungicide management to minimize development of fungicide resistance. With the knowledge of Phytophthora diversity in the nurseries, future research can concentrate on their role in crop quality reduction and methods to improve disease management.

\section{ACKNOWLEDGMENTS}

We thank S. Rooney-Latham, E. Lovig, M. Negrete, T. Irving, M. Soriano, A. Noguchi, J. Estoque, and A. Morris from CDFA for processing survey samples, conducting ELISA and PCR tests, and managing regulatory records; and P. Quan and N. Chan for laboratory support. We also thank the U.S. Department of Agriculture Forest Service, Pacific Southwest Research Station, for their financial support.

\section{LITERATURE CITED}

1. Alferi, S. A., Jr. 1970. Bougainvillea blight: A new disease caused by Phytophthora parasitica. Phytopathology 60:1806-1808.

2. Alvarez, L. A., Perez-Sierra, A. P., GarciaJimenez, J., Abad-Campos, P., Landeras, E., and Alzugaray, R. 2007. First report of leaf spot and twig blight of Rhododendron spp. caused by Phytophthora hibernalis in Spain. Plant Dis. 91:909.

3. Anonymous. 1997. Phytophthora ramorum Nursery Survey Manual. U.S. Dep. Agric. APHIS, Beltsville, MD.

4. Anonymous. 1997. Conventional PCR assays for the detection of Phytophthora ramorum. U.S. Dep. Agric. - APHIS, Beltsville, MD.

5. Anonymous. 2006. California Agricultural Resource Directory, 2006. California Department of Food and Agriculture, Sacramento.

6. Balci, Y., and Halmschlager, E. 2003. Phytophthora species in oak ecosystems in Turkey and their association with declining oak trees. Plant Pathol. 52:694-702.

7. Benson, D. M. 1980. Chemical control of Rhododendron dieback caused by Phy- tophthora heveae. Plant Dis. 64:684-686.

8. Brasier, C. M. 1983. Problems and prospects in Phytophthora research. Pages 351-364 in Phytophthora: Its Biology, Taxonomy, Ecology, and Pathology. D. C. Erwin, S. BartnickiGarcia, and P. H. Tsao, eds. American Phytopathological Society, St. Paul, MN.

9. Brasier, C. M., Cooke, D. E. L., Duncan, J. M., and Hansen, E. M. 2003. Multiple new phenotypic taxa from trees and riparian ecosystems in Phytophthora gonapodyides-P. megasperma ITS Clade 6, which tend to be hightemperature tolerant and either inbreeding or sterile. Mycol. Res. 107:277-290.

10. Bush, E. A., Hong, C. X., and Stromberg, E. L. 2003. Fluctuations of Phytophthora and Pythium spp. in components of a recycling irrigation system. Plant Dis. 87:1500-1506.

11. Bush, E. A., Stromberg, E. L., Hong, C., Richardson, P. A., and Kong, P. 2006. Illustration of key morphological characteristics of Phytophthora species identified in Virginia nursery irrigation water. Plant Health Progress. Online, doi:10.1094/PHP-2006-0621-01-RS.

12. Cooke, D. E. L., Drenth, A., Duncan, J. M., Wagels, G., and Brasier, C. M. 2000. A molecular phylogeny of Phytophthora and related Oomycetes. Fungal Genet. Biol. 30:17-32.

13. Davison, E. M., Drenth, A, Kumar, S., Mack, S., Mackie, A. E., and McKirdy, S. 2006. Pathogens associated with nursery plants imported into Western Australia. Australas. Plant Pathol. 35:473-475.

14. Donahoo, R., Blomquist, C. L., Thomas, S. L. Moulton, J. K., Cooke, D. E. L., and Lamour, K. H. 2006. Phytophthora foliorum sp. nov., a new species causing leaf blight of azalea. Mycol. Res. 110:1309-1322.

15. Donahoo, R. S., and Lamour, K. H. 2008. Characterization of Phytophthora species from leaves of nursery woody ornamentals in Tennessee. Hortscience 43:1833-1837.

16. Erwin, D. C., and Ribeiro, O. K. 1996. Phytophthora Diseases Worldwide. American Phytopathological Society, St. Paul, MN.

17. Ferguson, A. J., and Jeffers, S. N. 1999. Detecting multiple species of Phytophthora in container mixes from ornamental crop nurseries. Plant Dis. 83:1129-1136.

18. Gerlach, W. W. P., Hoitink, H. A. J., and Schmitthenner, A. F. 1976. Phytophthora citrophthora on Pieris japonica: Infection, sporulation, and dissemination. Phytopathology 66:302-308.

19. Greslebin, A. G., Hansen, E. M., Winton, L. M., and Rajchenberg, M. 2005. Phytophthora species from declining Austrocedrus chilensis forests in Patagonia, Argentina. Mycologia 97:218-228.

20. Hansen, E. M., Reeser, P., Davidson, J. M., Garbelotto, M., Ivors, K., Douhan, L., and Rizzo, D. M. 2003. Phytophthora nemorosa, a new species causing cankers and leaf blight of forest trees in California and Oregon, USA. Mycotaxon 88:129-138.

21. Hansen, E., Rizzo, D., and Garbelotto, M. 2005. Phytophthora species from oak and tanoak forests in California and Oregon. Proc. Sudden Oak Death 2nd Sci. Sympos.: The State of Our Knowledge. Gen. Tech. Rep. PSW-GTR-196.

22. Hardy, G. E. St. J., and Sivasithamparam, K. 1988. Phytophthora spp. associated with container-grown plants in nurseries in Western Australia. Plant Dis. 72:435-437.

23. Hayden, K. J., Rizzo, D., Tse, J., and Garbelotto, M. 2004. Detection and quantification of Phytophthora ramorum from California forests using a real-time polymerase chain reaction assay. Phytopathology 94:1075-1083.

24. Hong, C. X., Richardson, P. A., Kong, P., Jeffers, S. N., and Oak, S. W. 2006. Phytophthora tropicalis isolated from diseased leaves of Pieris japonica and Rhododendron 
catawbiense and found in irrigation water and soil in Virginia. Plant Dis. 90:525.

25. Hughes, K. J. D., Tomlinson, J. A., Griffin, R. L., Boonham, N., Inman, A. J., and Lane, C. R. 2006. Development of a one-step real-time polymerase chain reaction assay for diagnosis of Phytophthora ramorum. Phytopathology 96:975981.

26. Jeffers, S. N., and Martin, S. B. 1986. Comparison of two media selective for Phytophthora and Pythium species. Plant Dis. 70:1038-1043.

27. Jung, T., Nechwatal, J., Cooke, D. E., Hartmann, G. Blaschke, M., Oswald, W. F., Duncan, J. M., and Delatour, C. 2003. Phytophthora pseudosyringae sp. nov., a new species causing root and collar rot of deciduous tree species in Europe. Mycol. Res. 107:772-789.

28. Lee, S., Lee, J. P., Kim, K., and Shin, H. 2005. Root rot of Japanese angelica caused by Phytophthora cactorum in nursery and mycological characteristics of the isolates. Korean J. Mycol. 33:98-102.

29. MacDonald, J. D., Ali-Shtayeh, M. S., Kabashima, J., and Stites, J. 1994. Occurrence of Phytophthora species in recirculated nursery irrigation effluents. Plant Dis. 78:607-611.

30. Martin, F. N., and Tooley, P. W. 2003. Phylogenetic relationships of Phytophthora ramorum, $P$. nemorosa, and $P$. pseudosyringae, three species recovered from areas in California with sudden oak death. Mycol. Res. 107:1379-1391.

31. McIntosh, D. L. 1966. The occurrence of Phytophthora spp. in irrigation systems in British Columbia. Can. J. Bot. 44:1591-1596.

32. Miller, P. M. 1955. V-8 juice agar as a general purpose medium for fungi and bacteria. Phyto- pathology 45:461-462.

33. Neher, D., and Duniway, J. D. 1992. Dispersal of Phytophthora parasitica in tomato fields by furrow irrigation. Plant Dis. 76:582-586.

34. Orlikowski, L. B., Duda, B., and Szkuta, G. 2004. Phytophthora citricola on European beech and silver fir in Polish forest nurseries. J. Plant Prot. Res. 44:57-64.

35. Orlikowski, L. B., and Ptaszek, M. 2007. Phytophthora spp. in Polish ornamental nurseries. 1. Perennial plants, new hosts of P. cryptogea. J. Plant Prot. Res. 47:401-408.

36. Orlikowski, L. B., and Szkuta, G. 2003. Phytophthora citricola on Rhododendron spp. in Polish nurseries. J. Plant Prot. Res. 43:19-24.

37. Orlikowski, L. B., Trzewik, A., and Orlikowska, T. 2007. Water as a potential source of Phytophthora citricola. J. Plant Prot. Res. 47:125-132.

38. Rizzo, D. M., Garbelotto, M., Davidson, J. M., Slaughter, G. W., and Koike, S. T. 2002. Phytophthora ramorum and Sudden Oak Death in California: I. Host Relationships. USDA For. Serv. Gen. Tech. Rep. PSW-GTR-184.

39. Rizzo, D. M., Garbelotto, M., Davidson, J. M., Slaughter, G. W., and Koike, S. T. 2002. Phytophthora ramorum as the cause of extensive mortality of Quercus spp. and Lithocarpus densiflorus in California. Plant Dis. 86:205-214.

40. Rytkonen, A., Lilja, A., Petaisto, R. L., and Hantula, J. 2008. Irrigation water and Phytophthora cactorum in a forest nursery. Scand. J. For. Res. 23:404-411

41. Schwingle, B. W., Smith, J. A., and Blanchette, R. A. 2007. Phytophthora species associated with diseased woody ornamentals in Minnesota Nurseries. Plant Dis. 91:97-102.

42. Stamps, D. J., Waterhouse, G. M., Newhook, F.
J., and Hall, G. S. 1990. Revised tabular key to the species of Phytophthora. CAB Int. Mycol. Inst., Mycol. Pap. 162.

43. Themann, K. Werres, S., Luttmann, R and Diener, H.-A. 2002. Observations of Phy tophthora spp. In water recirculation systems in commercial hardy ornamental nursery stock. Eur. J. Plant Pathol. 108:337-343.

44. Varela, C. P., Vazquez, J. P. M., Casal, O. A and Martinez, C. R. 2007. First report of Phytophthora pseudosyringae on chestnut nursery stock in Spain. Plant Dis. 91:1517.

45. Von Broembsen, S. L. 1984. Distribution of Phytophthora cinnamomi in rivers of the South-western Cape Province. Phytophylactica 16:227-229.

46. Warfield. C. Y., Hwang, J., and Benson, D. M 2008. Phytophthora blight and dieback in North Carolina nurseries during a 2003 survey. Plant Dis. 92:474-481.

47. Werres, S., Marwitz, R., Man In't Veld, W. A., De Cock, A. W. A. M., Bonants, P. J. M., De Weerdt, M., Themann, K., Ilieva, E., and Baayen, R. P. 2001. Phytophthora ramorum sp. nov., a new pathogen on Rhododendron and Viburnum. Mycol. Res. 105:1155-1165.

48. White, T. J., Brun, T., Lee, S., and Taylor, J. 1990. Amplification and direct sequencing of fungal ribosomal RNA genes for phylogenetics. Pages 315-322 in: PCR Protocols: A Guide to Methods and Applications. M. A. Innis, D. H. Gelfand, J. J. Sninsky, and T. J. White, eds. Academic Press, San Diego, CA.

49. Wickland, A. C. Jensen, C. L. and Rizzo, D. M. 2008. Geographic distribution, disease symptoms and pathogenicity of Phytophthora nemorosa and Phytophthora pseudosyringae in California, USA. For. Pathol. 38:288-298. 